Correspondence

Olga C. Nunes

opnunes@fe.up.pt

\section{Gulosibacter molinativorax gen. nov., sp. nov., a molinate-degrading bacterium, and classification of 'Brevibacterium helvolum' DSM 20419 as Pseudoclavibacter helvolus gen. nov., sp. nov.}

\author{
Célia M. Manaia, ${ }^{1}$ Balbina Nogales, ${ }^{2,3} \dagger$ Norbert Weiss ${ }^{4}$ \\ and Olga C. Nunes ${ }^{5}$
${ }^{1}$ Escola Superior de Biotecnologia, Universidade Católica Portuguesa, 4200-072 Porto, Portugal
${ }^{2}$ Division of Microbiology, GBF - German Research Centre for Biotechnology, Braunschweig, Germany
${ }^{3}$ Area de Microbiologia, Universitat de les Illes Balears, Palma de Mallorca, Spain
${ }^{4}$ DSMZ - Deutsche Sammlung von Mikroorganismen und Zellkulturen, Mascheroder Weg $1 \mathrm{~b}$, D-38124 Braunschweig, Germany
${ }^{5}$ LEPAE - Departamento de Engenharia Química, Faculdade de Engenharia, Universidade do Porto, R. Dr Roberto Frias, 4200-465 Porto, Portugal

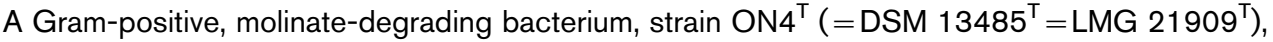
was isolated from a mixed bacterial culture able to mineralize the herbicide molinate. The strain was strictly aerobic, oxidase- and catalase-positive and non-acid-fast, with a growth temperature of $10-41^{\circ} \mathrm{C}$. It contained the major menaquinone MK-9 and a cell-wall peptidoglycan based on D-ornithine. 16S rDNA sequence analysis revealed that the strain formed a distinct line of descent in the family Microbacteriaceae, showing the highest $16 \mathrm{~S}$ rDNA similarity ( $95 \%)$ to members of the genus Curtobacterium and 'Brevibacterium helvolum' DSM 20419 (=ATCC 13715). The latter was reported to have the cell-wall peptidoglycan type B2 $\gamma$ and the major menaquinone MK-9, which are typical of Clavibacter, but it is clearly separated from this genus at the phylogenetic level. Based on low values of $16 \mathrm{~S}$ rDNA sequence similarity to previously described genera and their distinctive phenotypic characteristics, it is proposed that strains ON4 ${ }^{\top}$ and 'B. helvolum' DSM 20419 be classified as two novel genera and species, with the respective names Gulosibacter molinativorax gen. nov., sp. nov. and Pseudoclavibater helvolus gen. nov., sp. nov.
\end{abstract}

\section{INTRODUCTION}

The family Microbacteriaceae (Park et al., 1993; Stackebrandt et al., 1997) embraces a large group of actinomycetes with cell-wall peptidoglycan of the B-type (Schleifer \& Kandler, 1972). The family currently contains 16 genera, distinguished at the phenotypic level by a number of

Published online ahead of print on 28 November 2003 as DOI 10.1099/ijs.0.02851-0.

Abbreviation: DAB, 2,4-diaminobutyric acid.

The GenBank/EMBL/DDBJ accession number for the 16S rDNA sequence of isolate $\mathrm{ON} 4^{\top}$ is AJ306835.

tPresent address: Area de Microbiologia, Universitat de les Illes Balears, Palma de Mallorca, Spain.

Micrographs of cells of the novel species and details of fatty acid compositions are available as supplementary material in IJSEM Online. chemotaxonomic characteristics, including peptidoglycan diamino acids and respiratory menaquinone composition (Collins \& Bradbury, 1992; Evtushenko \& Takeuchi, 2003; Sheridan et al., 2003).

'Brevibacterium helvolum' DSM 20419 (=ATCC 13715), an organism isolated from butter, has peptidoglycan $\mathrm{B} 2 \gamma$, [L-DAB]-D-Glu-D-DAB (DAB is 2,4-diaminobutyric acid), unsaturated menaquinone with nine isoprene units (MK-9) (Schleifer \& Kandler, 1972; Sasaki et al., 1998) and the polyamines 2,3-diaminopropane and cadaverine (Altenburger et al., 1997). Based on comparative analysis of 16S rDNA, Rainey et al. (1994) showed that 'B. helvolum' DSM 20419 formed a separate subline of descent within the radiation of actinomycetes belonging to the family Microbacteriaceae. According to Rainey et al. (1994), this strain could represent the nucleus of a novel genus. 
Strain $\mathrm{ON} 4^{\mathrm{T}}$ was isolated from a microbial mixed culture enriched in molinate, which also included four strains of the genera Pseudomonas, Stenotrophomonas and Achromobacter (Barreiros et al., 2003). The strain used molinate as the only carbon, nitrogen and energy source and grew at herbicide concentrations up to $2 \mathrm{mM}$, although it did not perform its complete degradation (Barreiros et al., 2003). It exhibited the highest $16 \mathrm{~S}$ rDNA similarity to the misclassified strain 'B. helvolum' DSM 20419 and could not be affiliated to any previously described genus. In this paper, we describe the morphological, physiological, chemotaxonomic and phylogenetic characteristics of these organisms and propose to accommodate them into two novel genera.

\section{METHODS}

Determination of morphological, growth and biochemical characteristics. Wet mounts and staining methods followed by optical microscopic examination were used to assess cell morphology, Gram and Ziehl-Neelsen reactions, production of spores, accumulation of poly-hydroxybutyrate granules and motility, according to procedures described previously (Doetsch, 1981; Smibert \& Krieg, 1981). Cell morphology of isolate $\mathrm{ON} 4^{\mathrm{T}}$ was further studied by electron microscopy after negative staining with $2 \%(\mathrm{w} / \mathrm{v})$ sodium phosphotungstate $(\mathrm{pH} \mathrm{7 \cdot 0)}$ using a Hitachi H-600 transmission electron microscope at $75 \mathrm{kV}$.

Growth temperature, $\mathrm{pH}$ and salinity ranges were examined by measuring turbidity (at $610 \mathrm{~nm}$ ) of cultures in $250 \mathrm{ml} \mathrm{screw}$-capped Erlenmeyer flasks containing $50 \mathrm{ml} \mathrm{LB}$ medium (Carlton \& Brown, 1981) incubated in an orbital water-bath shaker. The $\mathrm{pH}$ range for growth was examined in medium buffered with $12 \mathrm{mM}$ MES (Sigma) at pH $5 \cdot 0-6 \cdot 0$ or with $15 \mathrm{mM}$ CAPS (Sigma) at $\mathrm{pH} 9 \cdot 5-$ $11 \cdot 0$. Anaerobic growth of strains and oxidase (tetramethyl-pphenylenediamine), catalase, nitrate reductase and Tweenase reactions were examined at $30^{\circ} \mathrm{C}$ as described by Smibert \& Krieg (1981) using 3-day cultures grown on LB agar (LA). Other enzymic activities were tested using the API ZYM system, following the instructions of the manufacturer. The nutritional pattern was characterized using the API 50CH system and a defined medium B (Manaia et al., 2003). The ability of strain $\mathrm{ON} 4^{\mathrm{T}}$ to use API $50 \mathrm{CH}$ carbon sources was also tested in mineral medium supplemented with different concentrations of yeast extract $(0 \cdot 01-0 \cdot 2 \%, \mathrm{w} / \mathrm{v})$. Additionally, the aerobic dissimilation of 95 carbon sources was tested using the Biolog GP microplate system, according to the manufacturer's indications.

Determination of chemotaxonomic characteristics. The polar lipids of strains $\mathrm{ON}^{\mathrm{T}}$ and DSM 20419 were characterized using cultures grown in $\mathrm{LB}$ medium, at $30^{\circ} \mathrm{C}$, at the late exponential phase of growth. Lipid extractions were performed as described previously (Tindall, 1990). Individual polar lipids were separated by two-dimensional TLC as described by Minnikin et al. (1977). For the analysis of methylated fatty acids (FAMEs) of strains $\mathrm{ON} 4^{\mathrm{T}}$ and DSM 20419, cells were grown for 3 days on LA medium at $30{ }^{\circ} \mathrm{C}$. FAME extraction and analysis were performed as described by Moreira et al. (2000). For the analysis of respiratory quinones, strains $\mathrm{ON} 4^{\mathrm{T}}$ and DSM 20419 were cultured on LA medium, harvested, freeze-dried and extracted according to Tindall (1989), and the extracts were analysed as described by Moreira et al. (2000). The peptidoglycan of strain $\mathrm{ON} 4^{\mathrm{T}}$ was analysed as described previously (Schleifer \& Kandler, 1972), using TLC on cellulose sheets instead of paper chromatography. L- and D-ornithine could be distinguished by their small but significant mobility in the solvent system used for the characterization of diamino acids. For the determination of DNA base composition of strains $\mathrm{ON} 4^{\mathrm{T}}$ and DSM
20419, genomic DNA was isolated as described by Cashion et al. (1977) and the DNA G + C content was analysed by HPLC (Mesbah et al., 1989).

$16 S$ rRNA sequence determination and phylogenetic analysis. The sequence of the $16 \mathrm{~S}$ rRNA gene of isolate $\mathrm{ON} 4^{\mathrm{T}}$ was determined after PCR amplification from total DNA extracts using primers 27f and 1492r (Lane, 1991) as described previously (Nogales et al., 2001). The nucleotide sequence of purified PCR products was determined by using the BigDye Terminator cycle sequencing kit and ABI377 and 310 sequencers (Applied Biosystems), according to the manufacturer's instructions. The nucleotide sequence was aligned with reference sequences using the ARB package (http://www. arb-home.de). Phylogenetic trees were constructed using the ARB package and the distance methods of neighbour-joining and Fitch [using the correction of the Jukes \& Cantor (1969) for calculation of evolutionary distances] as well as parsimony methods. Bootstrap analysis (1000 replicates) was done using the PHYLIP package (Felsenstein, 1989). Ambiguous nucleotide positions were excluded from the calculations.

\section{RESULTS AND DISCUSSION}

\section{Morphological, biochemical and growth characteristics}

On LA medium, strain $\mathrm{ON} 4^{\mathrm{T}}$ formed white, opaque colonies, $1 \mathrm{~mm}$ in diameter, while colonies of strain DSM 20419 were yellow and $2 \mathrm{~mm}$ in diameter. Both strains formed irregularly rod-shaped cells (see Supplementary Figure in IJSEM Online), and strain $\mathrm{ON} 4^{\mathrm{T}}$ had a tendency to form short filaments. Strains $\mathrm{ON} 4^{\mathrm{T}}$ and DSM 20419 stained as Gram-positive, were non-acid-fast and non-sporeforming, had no visible deposits of poly- $\beta$-hydroxybutyrate and were non-motile and catalase-positive. Both organisms were observed to be strictly aerobic and positive for oxidase, although a very weak reaction was observed for strain DSM 20419. Isolate $\mathrm{ON} 4^{\mathrm{T}}$ was able to reduce nitrate under both aerobic and anaerobic conditions, although growth did not occur in the absence of oxygen (Table 1).

The growth temperature optima were $28-30{ }^{\circ} \mathrm{C}$ for strain DSM 20419 and $35-37^{\circ} \mathrm{C}$ for strain $\mathrm{ON} 4^{\mathrm{T}}$, although the latter also grew well at $28-30^{\circ} \mathrm{C}$. Metabolic activities of strain $\mathrm{ON} 4^{\mathrm{T}}$ studied in the presence of vitamins or yeast extract were restricted to only 15 of 110 compounds tested and, of the few carbon sources utilized, most contained nitrogen. A slow reaction was observed with the only sugar, $\alpha$-D-glucose. Strain DSM 20419 was much more versatile metabolically and utilized a variety of organic compounds, including sugars, alcohols, organic acids, amino acids and nucleotides. Details of the physiological and biochemical characteristics of the strains are given in Table 1 and in the species descriptions.

\section{Chemotaxonomic characteristics}

Cell-wall analysis revealed that strain $\mathrm{ON} 4^{\mathrm{T}}$ had a B-type peptidoglycan based upon D-ornithine. Strains $\mathrm{ON} 4^{\mathrm{T}}$ and DSM 20419 had the major isoprenoid quinone MK-9 (about $95 \%$ ), with MK-8 as a minor component. The polar 
Table 1. Phenotypic characteristics of strains ON4 ${ }^{\top}$ and DSM $20419^{\top}$

Both strains produced alkaline phosphatase, esterase $\left(\mathrm{C}_{4}\right)$, esterase lipase $\left(\mathrm{C}_{8}\right)$, lipase $\left(\mathrm{C}_{14}\right)$, leucine arylamidase, valine arylamidase, cystine arylamidase, acid phosphatase and naphthol-AS-BI-phosphohydrolase. Neither strain produced trypsin, chymotrypsin, $\alpha$-galactosidase, $\beta$-glucosidase, $\beta$-glucuronidase, $N$-acetyl$\beta$-glucosaminidase, $\alpha$-mannosidase, $\alpha$-fucosidase or amylase. Both strains were positive or showed weak reactions for the utilization of pyruvic acid, methyl pyruvate, L-glutamic acid, 2,3-butanediol, adenosine, $2^{\prime}$-deoxyadenosine, inosine, thymidine, uridine, adenosine $5^{\prime}$-monophosphate, thymidine $5^{\prime}$-monophosphate and uridine $5^{\prime}$-monophosphate. Neither strain was able to use the following carbon sources: adonitol, dulcitol, arbutin, starch, methyl $\beta$-D-glucoside, salicin, $\alpha$ - and $\beta$-cyclodextrin, glycogen, inulin, mannan, $N$-acetyl-D-mannosamine, amygdalin, D- and L-arabinose, D- and L-arabitol, erythritol, D- and L-fucose, D-galactose, D-galacturonic acid, maltotriose, D-lyxose, D-melezitose, D-melibiose, L-xylose, methyl $\alpha$ - and $\beta$-D-galactoside, methyl $\beta$-xyloside, 3-methyl-D-glucose, methyl $\alpha$-D-glucoside, methyl $\alpha$-D-mannoside, palatinose, L-rhamnose, D-ribose, L-sorbose, sedoheptulosan, stachyose, D-tagatose, xylitol, acetic acid, $\alpha$ - and $\beta$-hydroxybutyric acid, $\alpha$-ketoglutaric acid, $\alpha$-ketovaleric acid, lactamide, D-lactic acid methyl ester, D- and L-malic acid, monomethyl succinate, propionic acid, succinamic acid, succinic acid, $\mathrm{N}$-acetyl-L-glutamic acid, alaninamide, D-alanine, L-alanyl glycine, L-asparagine, glycyl L-glutamic acid, L-pyroglutamic acid, L-serine, fructose 6-phosphate, glucose 1-phosphate, glucose 6-phosphate and DL- $\alpha$-glycerol phosphate. w, Weak.

\begin{tabular}{|c|c|c|}
\hline Characteristic & $\begin{array}{l}\text { Strain } \\
\mathrm{ON} 4^{\mathrm{T}}\end{array}$ & $\begin{array}{c}\text { Strain } \\
\text { DSM } 20419^{\mathrm{T}}\end{array}$ \\
\hline Colony colour & White & Yellow \\
\hline \multicolumn{3}{|l|}{ Range of growth: } \\
\hline Temperature $\left({ }^{\circ} \mathrm{C}\right)$ & $10-41$ & $10-35$ \\
\hline $\mathrm{pH}$ & $5 \cdot 5-10 \cdot 5$ & $6-10$ \\
\hline $\mathrm{NaCl}(\%, \mathrm{w} / \mathrm{v})$ & $0-7$ & $0-6$ \\
\hline Reduction of nitrate & $+($ nitrite $)$ & - \\
\hline \multicolumn{3}{|l|}{ Presence of: } \\
\hline$\beta$-Galactosidase & - & + \\
\hline$\alpha$-Glucosidase & - & + \\
\hline \multicolumn{3}{|l|}{ Utilization of: } \\
\hline $\begin{array}{l}\text { Tween 40, } N \text {-acetyl D-glucosamine, cellobiose, } \\
\text { D-fructose, gentiobiose, lactulose, D-mannose, } \\
\text { D-psicose, sucrose, D-trehalose, turanose, } \\
\text { D-xylose, glycerol, D-mannitol, D-sorbitol, } \\
\text { D-gluconic acid, } \gamma \text {-hydroxybutyric acid, } \\
\text { L-lactic acid }\end{array}$ & - & + \\
\hline p-Hydroxyphenylacetic acid & + & - \\
\hline$\alpha$-D-Glucose & $\mathrm{W}$ & + \\
\hline Dextrin & - & $\mathrm{W}$ \\
\hline L-Alanine, aesculin & - & + \\
\hline Putrescine & + & $\mathrm{W}$ \\
\hline
\end{tabular}

lipid patterns of both strains were composed of diphosphatidylglycerol, phosphatidylglycerol and one unknown minor glycolipid. The predominant cellular fatty acids detected in strains $\mathrm{ON} 4{ }^{\mathrm{T}}$ and DSM 20419 were anteiso$\mathrm{C}_{15: 0}(46.9$ and $45 \%)$, iso- $\mathrm{C}_{16: 0}(33 \cdot 2$ and $23 \cdot 3 \%)$ and anteiso- $\mathrm{C}_{17: 0}(9 \cdot 7$ and $19 \cdot 4 \%$ ) (see Supplementary Table in IJSEM Online). The DNA G+C contents were $64.5 \mathrm{~mol} \%$ for strain $\mathrm{ON} 4^{\mathrm{T}}$ and $67.0 \mathrm{~mol} \%$ for DSM 20419. The above characteristics are typical of the family Microbacteriaceae (Collins \& Bradbury, 1992; Evtushenko \& Takeuchi, 2003).

\section{$16 S$ rDNA sequence analysis}

Nearly the complete nucleotide sequence of the 16S rRNA gene $(1430 \mathrm{nt})$ of isolate $\mathrm{ON} 4^{\mathrm{T}}$ was determined. Phylogenetic analysis based on 16S rDNA sequences supported the affiliation of the strain to the family Microbacteriaceae. The strain formed a distinct lineage adjacent to ' $B$. helvolum' DSM 20419 (Fig. 1) when a different set of strains and different algorithms were used to generate the phylogenetic trees, although the stability of the branch was not confirmed by a high bootstrap resampling value (not shown). Pairwise sequence similarities calculated for $16 \mathrm{~S}$ rDNA 


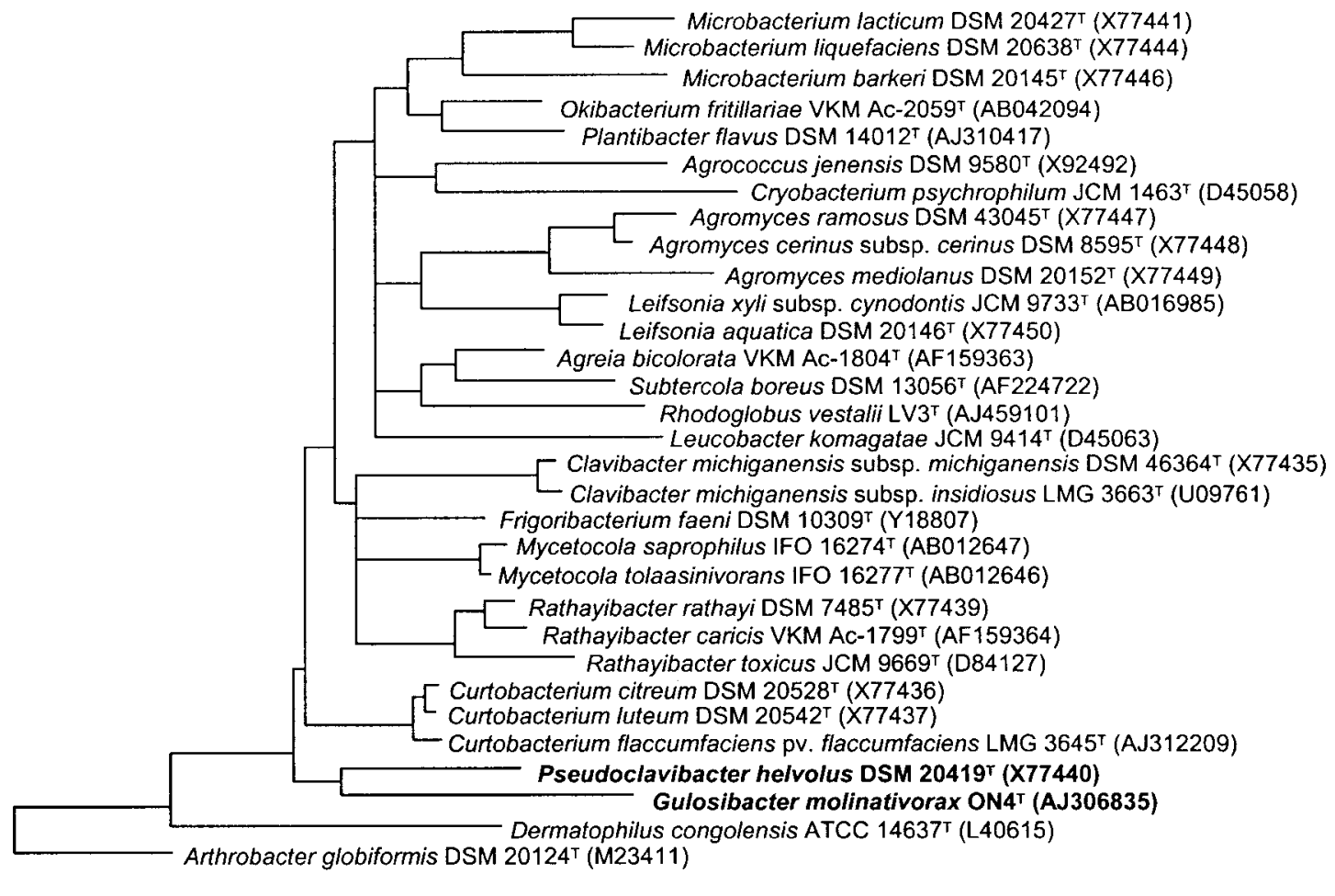

0.05

Fig. 1. Phylogenetic relationships of the $16 \mathrm{~S}$ rDNA sequences of strains ON4 ${ }^{\top}$ and ' $B$. helvolum' DSM 20419 with related genera within the family Microbacteriaceae. Evolutionary distance matrices were calculated using the correction of Jukes \& Cantor (1969). The dendrogram was constructed using the neighbour-joining algorithm (Saitou \& Nei, 1987), using a 50\% conservation filter (total positions compared, 1331). Multifurcations were introduced using the ARB package for those branches that did not show a stable position when different algorithms were used for the analysis, which corresponded to branches with low bootstrap values (1000 replicates were done). The 16S rDNA sequence of Arthrobacter globiformis DSM $20124^{\top}$ was used as the outgroup.

sequences in the region between positions 52 and 1459 (Escherichia coli numbering) revealed that $\mathrm{ON} 4^{\mathrm{T}}$ exhibited the highest similarity to ' $B$. helvolum' and representatives of Curtobacterium flaccumfaciens ( 95\%). The $16 \mathrm{~S}$ rDNA sequence of ' $B$. helvolum' was most similar to the sequence of Curtobacterium luteum (95.4\%).

\section{Taxonomic conclusions}

The similarities of the 16S rDNA sequences of strains $\mathrm{ON}^{\mathrm{T}}$ and ' $B$. helvolum' DSM 20419 and each of these strains and other members of the Microbacteriaceae are within the range of 16S rRNA gene sequence similarities observed between those of the genera of the family. The organisms are also distinguished from most genera of the family by a combination of their menaquinone and peptidoglycan composition, which are salient chemotaxonomic markers of the genera belonging to the family Microbacteriaceae (Sasaki et al., 1998; Evtushenko \& Takeuchi, 2003). Although strain $\mathrm{ON} 4^{\mathrm{T}}$ is similar in these characteristics to Curtobacterium, it can be differentiated from this genus by positive oxidase reaction, a higher optimal temperature for growth, a lower $\mathrm{G}+\mathrm{C}$ content and the specific nutritional pattern (Table 2). Strain DSM 20419 has the peptidoglycan and the major menaquinone typical of the genus Clavibacter (Sasaki et al., 1998). However, a distinctive polyamine pattern (Altenburger et al., 1997) along with some physiological properties clearly separate it from Clavibacter species. Thus, based on both molecular genetic and phenotypic data, it is proposed to classify the studied organisms in two novel genera and species, Gulosibacter molinativorax gen. nov., sp. nov. (type strain $\mathrm{ON} 4^{\mathrm{T}}=$ DSM $13405^{\mathrm{T}}=\mathrm{LMG} 21909^{\mathrm{T}}$ ) and Pseudoclavibacter helvolus gen. nov., sp. nov. (type strain DSM $20419^{\mathrm{T}}=$ ATCC $13715^{\mathrm{T}}$ ).

\section{Description of Gulosibacter gen. nov.}

Gulosibacter (Gu.lo'si.bac.ter. L. adj. gulosus fond of titbits, dainty feeder, N.L. masc. n. bacter rod; N.L. masc. n. Gulosibacter rod fond of titbits).

Irregular rod-shaped cells; may tend to form short filaments and to branch. Gram-positive. Non-spore-forming. Aerobic. Catalase-positive. Chemo-organotrophic. The diamino acid of peptidoglycan is D-ornithine. The major respiratory quinone is menaquinone MK-9. Polar lipids 
Table 2. Differentiating characteristics of strains $O N 4^{\top}$ and $D S M 20419^{\top}$ and related genera of the family Microbacteriaceae

Taxa: 1, strain ON4 $4^{\mathrm{T}}$; 2, strain DSM $20419^{\mathrm{T}}$; 3, Curtobacterium; 4, Clavibacter. Data were obtained from Collins \& Bradbury (1992), Altenburger et al. (1997), Sasaki et al. (1998), Behrendt et al. (2002) and this study. Characteristics are scored as: +, positive; -, negative; NA, no data available; W, weak; $\mathrm{d}$, variable characteristic among the genus. Abbreviations: DAP, 2,3-diaminopropane; CAD, cadaverine; SPD, spermidine; SPM, spermine.

\begin{tabular}{|c|c|c|c|c|}
\hline Characteristic & 1 & 2 & 3 & 4 \\
\hline Optimal growth temperature $\left({ }^{\circ} \mathrm{C}\right)$ & $35-37$ & $28-30$ & $25-30$ & $21-26$ \\
\hline Oxidase test & + & $\mathrm{W}$ & - & - \\
\hline \multicolumn{5}{|l|}{ Utilization of: } \\
\hline m-Inositol & - & $\mathrm{W}$ & + & $\mathrm{d}$ \\
\hline$\alpha$-D-Lactose & - & + & + & d \\
\hline D-Maltose & - & + & + & $\mathrm{d}$ \\
\hline D-Melibiose & - & - & + & - \\
\hline D-Melezitose & - & - & + & - \\
\hline D-Raffinose & - & + & - & - \\
\hline D-Ribose & - & - & + & $\mathrm{d}$ \\
\hline Tween 80 & - & + & $\mathrm{d}$ & - \\
\hline Diamino acid of peptidoglycan & D-Orn & DL-DAB & D-Orn & DL-DAB \\
\hline Major polyamines & NA & DAP, CAD & SPD, SPM & SPD, SPM \\
\hline DNA G $+\mathrm{C}$ content $(\mathrm{mol} \%)$ & 65 & 67 & $68-75$ & 65-78 \\
\hline Common habitat/site of isolation & $\begin{array}{l}\text { Herbicide-contaminated } \\
\text { soil and water }\end{array}$ & Butter & $\begin{array}{c}\text { Plant } \\
\text { material }\end{array}$ & $\begin{array}{c}\text { Plant } \\
\text { material }\end{array}$ \\
\hline
\end{tabular}

are diphosphatidylglycerol, phosphatidylglycerol and an unknown glycolipid. The predominant fatty acids are 12-methyl-tetradecanoic acid (anteiso- $\mathrm{C}_{15: 0}$ ), 14-methylpentadecanoic acid (iso- $\mathrm{C}_{16: 0}$ ) and 14-methyl-hexadecanoic acid (anteiso- $\mathrm{C}_{17: 0}$ ). The DNA $\mathrm{G}+\mathrm{C}$ content is about $65 \mathrm{~mol} \%$. The type species is Gulosibacter molinativorax.

\section{Description of Gulosibacter molinativorax sp. nov.}

Gulosibacter molinativorax [mo.li.na'ti.vo.rax. N.L. n. molinas molinate (a herbicide); L. adj. vorax devouring, ravenous, voracious; N.L. masc. adj. molinativorax molinate-degrading].

Irregular rod-shaped cells, $0 \cdot 8-1 \cdot 0 \mu \mathrm{m}$ long and $0 \cdot 5-$ $0.6 \mu \mathrm{m}$ wide, with tendency to form short filaments and branching. Non-motile. Colonies grown on LA medium are white and about $1 \mathrm{~mm}$ in diameter after $48-72 \mathrm{~h}$ of growth. Gram-positive. Strictly aerobic. Oxidase test is positive. Mesophilic: growth occurs at $10-41{ }^{\circ} \mathrm{C}$, with optimum growth at $35-37^{\circ} \mathrm{C}$. The $\mathrm{pH}$ growth range is $5 \cdot 5-10 \cdot 5$. Maximal growth rate is observed in the presence of $1 \%$ (w/v) $\mathrm{NaCl} ; 8 \% \mathrm{NaCl}$ inhibits growth. Nitrate is reduced to nitrite. A few organic compounds, including putrescine, methyl pyruvate, $p$-hydroxyphenylacetic acid, adenosine, inosine, thymidine and uridine, are utilized. Growth occurs in mineral medium supplemented with the thiocarbamate herbicide molinate. The DNA G $+\mathrm{C}$ content is $64 \cdot 5 \mathrm{~mol} \%$.

The type strain, ON4 ${ }^{\mathrm{T}}\left(=\mathrm{DSM} 13485^{\mathrm{T}}=\mathrm{LMG} 21909^{\mathrm{T}}\right.$ ), was isolated from a mixture of contaminated soil and water collected from a site of effluent discharge of a molinateproducing chemical plant in southern Portugal.

\section{Description of Pseudoclavibacter gen. nov.}

Pseudoclavibacter (Pseu.do.cla'vi.bac.ter. Gr. adj. pseudes false; N.L. masc. n. Clavibacter a bacterial generic name; N.L. masc. n. Pseudoclavibacter false Clavibacter).

Forms rod-shaped cells. Non-spore-forming. Grampositive. Aerobic, catalase-positive. Chemo-organotrophic; various organic compounds are used as carbon and energy sources, including sugars, alcohols, organic acids and nitrogenated bases. The peptidoglycan is B2 $\gamma$ [L-DAB]-DGlu-D-DAB (Schleifer \& Kandler, 1972; Sasaki et al., 1998). Menaquinone MK-9 is the major respiratory quinone. Polar lipids are diphosphatidylglycerol, phosphatidylglycerol and an unknown glycolipid. The predominant fatty acids are 12-methyl-tetradecanoic acid (anteiso- $\mathrm{C}_{15: 0}$ ), 14methyl-pentadecanoic acid (iso- $\mathrm{C}_{16: 0}$ ) and 14-methylhexadecanoic acid (anteiso- $\mathrm{C}_{17: 0}$ ). Major polyamines are 1,3-diaminopropane and cadaverine (Altenburger et al., 1997). The G $+C$ content of DNA is about $67 \mathrm{~mol} \%$. The type species is Pseudoclavibacter helvolus.

\section{Description of Pseudoclavibacter helvolus sp. nov.}

Pseudoclavibacter helvolus (hel.vo'lus. L. adj. helvolus pale yellow, yellowish). 
Irregular rod-shaped cells, $0 \cdot 9-1 \cdot 1 \mu \mathrm{m}$ long and $0 \cdot 4-0 \cdot 5 \mu \mathrm{m}$ wide. Non-motile. Colonies grown on LA medium are yellow and about $2-3 \mathrm{~mm}$ in diameter after $48-72 \mathrm{~h}$ of growth. Gram-positive. Strictly aerobic. Oxidase reaction is weakly positive. Mesophilic; growth occurs at $10-35^{\circ} \mathrm{C}$, with optimum growth at $28-30^{\circ} \mathrm{C}$. The $\mathrm{pH}$ growth range is 6-10. Maximal growth rate is observed in the presence of $1 \%(\mathrm{w} / \mathrm{v}) \mathrm{NaCl} ; 8 \% \mathrm{NaCl}$ inhibits growth. Aesculin, L-alanine, $\alpha$-D-glucose, D-fructose, $\alpha$-D-lactose, D-maltose, sucrose, D-raffinose, $N$-acetyl-D-glucosamine, glycerol, D-mannitol, pyruvic acid, methyl pyruvate, Tween 80, adenosine, 2'-deoxyadenosine, inosine, thymidine and uridine are utilized. Lipases are produced. The DNA $\mathrm{G}+\mathrm{C}$ content is $67 \mathrm{~mol} \%$.

The type strain is DSM $20419^{\mathrm{T}}\left(=\mathrm{ATCC} 13715^{\mathrm{T}}\right)$, isolated from butter.

\section{ACKNOWLEDGEMENTS}

This work was supported financially by the National Foundation for Science and Technology from Ministry of Science and Technology (project PRAXIS/P/BIO/12193/1998). Dr F. Hierro and Professor J. Lalucat are acknowledged for their help during electron microscopy observations.

\section{REFERENCES}

Altenburger, P., Kämpfer, P., Akimov, V. N., Lubitz, W. \& Busse, H.-J. (1997). Polyamine distribution in actinomycetes with group B peptidoglycan and species of the genera Brevibacterium, Corynebacterium, and Tsukamurella. Int J Syst Bacteriol 47, 270-277.

Barreiros, L., Nogales, B., Manaia, C. M., Silva Ferreira, A. C., Pieper, D. H., Reis, M. A. \& Nunes, O. C. (2003). A novel pathway for mineralization of the thiocarbamate herbicide molinate by a defined bacterial mixed culture. Environ Microbiol 5, 944-953.

Behrendt, U., Ulrich, A., Schumann, P., Naumann, D. \& Suzuki, K. (2002). Diversity of grass-associated Microbacteriaceae isolated from the phyllosphere and litter layer after mulching the sward; polyphasic characterization of Subtercola pratensis sp. nov., Curtobacterium herbarum sp. nov. and Plantibacter flavus gen. nov., sp. nov. Int J Syst Evol Microbiol 52, 1441-1454.

Carlton, B. C. \& Brown, B. J. (1981). Gene mutation. In Manual of Methods for General Microbiology, pp. 409-443. Edited by P. Gerhardt, R. G. E. Murray, R. N. Costilow, E. W. Nester, W. A. Wood, N. R. Krieg \& G. H. Phillips. Washington, DC: American Society for Microbiology.

Cashion, P., Holder-Franklin, M. A., McCully, J. \& Franklin, M. (1977). A rapid method for the base ratio determination of bacterial DNA. Anal Biochem 81, 461-466.

Collins, M. D. \& Bradbury, J. F. (1992). The genera Agromyces, Aureobacterium, Clavibacter, Curtobacterium, and Microbacterium. In The Prokaryotes, 2nd edn, pp. 1355-1368. Edited by A. Balows, H. G. Trüper, M. Dworkin, W. Harder \& K. H. Schleifer. New York: Springer.

Doetsch, R. N. (1981). Determinative methods of light microscopy. In Manual of Methods for General Microbiology, pp. 21-33. Edited by P. Gerhardt, R. G. E. Murray, R. N. Costilow, E. W. Nester, W. A. Wood, N. R. Krieg \& G. H. Phillips. Washington, DC: American Society for Microbiology.
Evtushenko, L. I. \& Takeuchi, M. (2003). The family Microbacteriaceae. In The Prokaryotes: an Evolving Electronic Resource for the Microbiological Community, 3rd edn, release 3.14, 31 July 2003. Edited by M. Dworkin et al. New York: Springer. http://link.springer-ny.com/link/service/books/10125/

Felsenstein, J. (1989). PHYLIP - phylogeny inference package. Cladistics 5, 164-166.

Jukes, T. H. \& Cantor, C. R. (1969). Evolution of protein molecules. In Mammalian Protein Metabolism, pp. 21-132. Edited by H. N. Munro. New York: Academic Press.

Lane, D. J. (1991). 16S/23S rRNA sequencing. In Nucleic Acid Techniques in Bacterial Systematics, pp. 115-175. Edited by E. Stackebrandt \& M. Goodfellow. Chichester: Wiley.

Manaia, C. M., Nunes, O. C. \& Nogales, B. (2003). Caenibacterium thermophilum gen. nov., sp. nov., isolated from a thermophilic aerobic digester of municipal sludge. Int J Syst Evol Microbiol 53, 1375-1382.

Mesbah, M., Premachandran, U. \& Whitman, W. B. (1989). Precise measurement of the $\mathrm{G}+\mathrm{C}$ content of deoxyribonucleic acid by high-performance liquid chromatography. Int J Syst Bacteriol 39, 159-167.

Minnikin, D. E., Patel, P. V., Alshamaony, L. \& Goodfellow, M. (1977). Polar lipid composition in the classification of Nocardia and related bacteria. Int J Syst Bacteriol 27, 104-117.

Moreira, C., Rainey, F. A., Nobre, M. F., da Silva, M. T. \& da Costa, M. S. (2000). Tepidimonas ignava gen. nov., sp. nov., a new chemolithoheterotrophic and slightly thermophilic member of the $\beta$-Proteobacteria. Int $J$ Syst Evol Microbiol 50, 735-742.

Nogales, B., Moore, E. R. B., Llobet-Brossa, E., Rossello-Mora, R., Amann, R. \& Timmis, K. N. (2001). Combined use of $16 \mathrm{~S}$ ribosomal DNA and $16 \mathrm{~S}$ rRNA to study the bacterial community of polychlorinated biphenyl-polluted soil. Appl Environ Microbiol 67, 1874-1884.

Park, Y. H., Suzuki, K., Yim, D. G. \& 7 other authors (1993). Suprageneric classification of peptidoglycan group B actinomycetes by nucleotide sequencing of $5 \mathrm{~S}$ ribosomal RNA. Antonie van Leeuwenhoek 94, 307-313.

Rainey, F., Weiss, N., Prauser, H. \& Stackebrandt, E. (1994). Further evidence for the phylogenetic coherence of actinomycetes with group B-peptidoglycan and evidence for the phylogenetic intermixing of the genera Microbacterium and Aureobacterium as determined by $16 \mathrm{~S}$ rDNA analysis. FEMS Microbiol Lett 118, 135-140.

Saitou, N. \& Nei, M. (1987). The neighbor-joining method: a new method for reconstructing phylogenetic trees. Mol Biol Evol 4, 406-425.

Sasaki, J., Chijimatsu, M. \& Suzuki, K. (1998). Taxonomic significance of 2,4-diaminobutyric acid isomers in the cell wall peptidoglycan of actinomycetes and reclassification of Clavibacter toxicus as Rathayibacter toxicus comb. nov. Int J Syst Bacteriol 48, 403-410.

Schleifer, K. H. \& Kandler, O. (1972). Peptidoglycan types of bacterial cell walls and their taxonomic implications. Bacteriol Rev 36, 407-477.

Sheridan, P. P., Loveland-Curtze, J., Miteva, V. I. \& Brenchley, J. E. (2003). Rhodoglobus vestalii gen. nov., sp. nov., a novel psychrophilic organism isolated from an Antarctic Dry Valley lake. Int J Syst Evol Microbiol 53, 985-994.

Smibert, R. M. \& Krieg, N. R. (1981). General characterization. In Manual of Methods for General Microbiology, pp. 409-443. Edited by P. Gerhardt, R. G. E. Murray, R. N. Costilow, E. W. Nester, W. A. 
Wood, N. R. Krieg \& G. H. Phillips. Washington, DC: American Society for Microbiology.

Stackebrandt, E., Rainey, F. A. \& Ward-Rainey, N. L. (1997).

Proposal for a new hierarchic classification system, Actinobacteria classis nov. Int J Syst Bacteriol 47, 479-491.
Tindall, B. J. (1989). Fully saturated menaquinones in the archaebacteriun Pyrobaculum islandicum. FEMS Microbiol Lett 60, 251-254.

Tindall, B. J. (1990). A comparative study of the lipid composition of Halobacterium saccharovorum from various sources. Syst Appl Microbiol 13, 128-130. 